\title{
40 Years of Policy Evolution of Chinese Farmer Cooperative Organization - Quantitative Analysis of Policy Text Based on the No. 1 Central Document
}

\author{
Li-Wei Xing ${ }^{1}$ \\ ${ }^{1}$ Shandong Technology and Business University, Yantai, Shandong, China \\ Correspondence: Li-Wei Xing, Shandong Technology and Business University, Yantai, Shandong, China. E-mail: \\ 749960435@qq.com
}

Received: June 4, 2021 Accepted: June 18, 2021 Online Published: June 22, 2021

doi:10.5539/par.v10n2p29 URL: http://dx.doi.org/10.5539/par.v10n2p29

\begin{abstract}
The issue of agricultural and rural farmers is a fundamental issue related to the national economy and people's livelihood. Solving farmer issues is always the top priority of the central government. At present, the construction of socialism with Chinese characteristics has entered a new era. Farmer cooperative organization have played an important role in agricultural output and farmers' economic income. Through text comprehensive analysis and policy tool analysis, the policies of farmer cooperative organization involved in the No.1 Central Document from 1982 to 1986 and 2004 to 2020 are sorted out, mainly including the evolution of the name of farmer cooperative organization and the policy support for the development of farmer cooperative organization. Chinese future farmer cooperative organization policies should focus on further improving the system construction of farmer cooperative organization and cultivating talents for farmer cooperatives.
\end{abstract}

Keywords: No. 1 Central Document, farmer, organization

\section{Introduction}

After the reform and opening up, the Chinese government issued the No.1 Central Document on agriculture for five consecutive years from 1982 to 1986. This is the five No.1 Central Documents formulated to consolidate the household contract responsibility system related to production after the implementation of the household contract responsibility system across the country, which provides policy guarantees for granting farmers the right to manage land and solving the problem of food and clothing in rural areas. In the mid to late 1980s, the focus of reform gradually shifted from rural to urban areas, and the urban economy began to rise. The urban-rural gap that had been gradually narrowed was once again widened. After entering the 1990s, farmers' taxes and fees have continued to increase, and the construction of rural people's livelihood has stagnated or even regressed, and farmers' enthusiasm for production has been seriously frustrated. In the 21 st century, the grim situation in the countryside has not been improved, and the contradiction between grassroots organizations and farmers has continued to deepen. In 2003, the national grain output declined, and farmers' enthusiasm for production fell to a low point. Under such circumstances, the Chinese government's policy focus has returned to the rural area. From 2004 to 2020, the No. 1 Central Document has focused on rural issues for 17 consecutive years.

As of the end of August 2019, there were 1.933 million farmer cooperative organizations nationwide. Farmer cooperative organization have become an important new type of agricultural business and an important force in the construction of modern agriculture. Under the background of the rapid growth of cooperatives, we have sorted out the policy connotation of farmer cooperative organizations in the No.1 Central Document and grasped the development trend of farmer cooperative organizations. According to the policy tools, it analyzes the problems existing in the policies of farmer cooperative organization, and puts forward the focus of the farmer cooperative organization policies in the future. The article uses qualitative data analysis software NVivo 11 to code the No. 1 central document, summarizes and summarizes the types of policy tools, and puts forward reasonable suggestions for existing problems.

\section{Evolution of the Name of Farmer Cooperative Organization}

Judging from the No. 1 Central Document of the past years, the name of the cooperative organization is divided into three stages. The No. 1 Central Document from 1982 to 1986 describes the cooperative organization as a 
regional cooperative economic organization. From 2004 to 2012, it was expressed as a farmer professional cooperative organization. However, in the process of development, cooperative organizations have gradually surpassed the scope of professional cooperative operations and services. In order to encourage the development of cooperative organizations and fully reflect the development trend of cooperative organizations, after 2013, the No.1 Central Document officially referred to cooperative organizations as farmer cooperative organizations., Not highlighting "professional".

\section{Key Points of Policy Concern for Farmer Cooperative Organization}

\subsection{Demonstration Construction of Farmer Cooperative Organizations}

For a long time, farmer cooperative organizations have faced problems such as irregular and random internal operation mechanisms on the one hand, and shortage of funds on the other. The existence of these problems leads to insufficient attractiveness and cohesion of cooperative organizations, resulting in poor sustainable development capabilities of cooperative organizations. How to regulate rural cooperative organizations and solve these problems in cooperative organizations? The No.1 Central Document of Committee after 2007 proposed to establish rural cooperative demonstration organizations and standardize the internal mechanisms of farmer cooperative organizations (Wang Shuguang,2008). Figure 1 lists the policies of the No.1 Central Document for the demonstration and construction of farmer cooperative organizations over the years.

\begin{tabular}{|c|l|}
\hline Years & \multicolumn{1}{|c|}{ Policy content } \\
\hline 2007 & $\begin{array}{l}\text { 1.Increase the scale of funds for demonstration projects for the construction of farmer } \\
\text { cooperative organizations, and focus on supporting farmers' professional cooperative } \\
\text { organizations to carry out marketing, information services, technical training, processing and } \\
\text { storage of agricultural products, and procurement of agricultural materials. }\end{array}$ \\
\hline 2008 & $\begin{array}{l}\text { 1.Continue to implement agricultural standardization demonstration projects, and support } \\
\text { leading enterprises, farmer cooperative organizations, science and technology demonstration } \\
\text { households, and large planting and raising households to take the lead in implementing } \\
\text { standardized production. }\end{array}$ \\
\hline 2009 & $\begin{array}{l}\text { 1.Promote leading enterprises, farmer cooperative organizations, and major professional } \\
\text { households to take the lead in implementing standardized production, and support the } \\
\text { establishment of green and organic agricultural products production bases. } \\
\text { 2.Accelerate the development of specialized farmer cooperative organizations and carry out } \\
\text { demonstration cooperative construction actions. }\end{array}$ \\
\hline 2010 & $\begin{array}{l}\text { 1.Vigorously develop farmers' professional cooperative organizations, in-depth promotion of } \\
\text { demonstration cooperatives, and provide subsidies to cooperative organizations with strong } \\
\text { service capabilities and good democratic management. }\end{array}$ \\
\hline 2012 & $\begin{array}{l}\text { 1.Increase support, strengthen counseling services, promote demonstration organization } \\
\text { construction actions, and promote standardized operation of farmer cooperative organizations. }\end{array}$ \\
\hline 2013 & $\begin{array}{l}\text { 1.Implement a mechanism for joint evaluation of model societies by departments, establish a } \\
\text { directory of model organizations at different levels, and take model organizations as the focus } \\
\text { of policy support. }\end{array}$ \\
\hline $\begin{array}{l}\text { 1.Encourage the development of various forms of farmer cooperative organizations such as } \\
\text { professional cooperation and share-holding cooperation, guide standardized operations, and } \\
\text { focus on strengthening capacity building. }\end{array}$ \\
$\begin{array}{l}\text { 1.Guide farmer cooperative organizations to broaden their service areas, promote } \\
\text { standardized development, implement an annual report publicity system, and further promote } \\
\text { the creation of demonstration organizations. }\end{array}$ \\
\hline
\end{tabular}




\begin{tabular}{|c|l|}
\hline 2016 & $\begin{array}{l}\text { 1.Strengthen the construction of farmer cooperative organizations and support cooperative } \\
\text { organizations to develop agricultural products processing and distribution and direct supply } \\
\text { and direct sales. }\end{array}$ \\
\hline 2017 & $\begin{array}{l}\text { 1.Strengthen the standardized construction of farmer cooperatives, and actively develop the } \\
\text { "three-in-one" comprehensive cooperation of production, supply and marketing, and credit. }\end{array}$ \\
\hline 2019 & $\begin{array}{l}\text { 1.Carry out farmer cooperatives to improve the norms and further promote the construction of } \\
\text { model cooperative organizations. }\end{array}$ \\
\hline
\end{tabular}

Figure 1. Farmer cooperation demonstration organization policy

\subsection{Policy Support of Farmer Cooperative Organization}

\subsubsection{Legal Policy}

Compared with the development history of foreign cooperative organizations, Chinese cooperative organizations have a shorter development time and are still in their infancy. They have less practical experience in the development of cooperative organizations, and there are many problems such as unclear positioning and irregular development. Therefore, China urgently needs to improve the corresponding laws and regulations as soon as possible.

\subsubsection{Funding Policy}

Most of the cooperative organizations in China did not have much registered capital at the beginning of their establishment. In addition, most farmers themselves are the demanders of funds and cannot buy more shares when they join the cooperative organization. Therefore, most cooperative organizations naturally have The problem of insufficient development funds. With the continuous expansion of the scale of cooperative organizations, the contradiction between the supply and demand of funds for cooperative organizations has become more prominent. In order to speed up the development of cooperative organizations, the central government has increased its financial support and subsidies for cooperative organizations.

\subsubsection{Personnel Policy}

Comprehensively improving the quality of the employees of cooperative organizations, especially the leaders of cooperatives, is the basis and prerequisite for accelerating the development of cooperative organizations. Increasing the training of talents for cooperative organizations and comprehensively improving the quality of participants in cooperative organizations are the talent guarantee for the further development and growth of cooperative organizations.

\subsubsection{Tax Policy}

The central government has always attached great importance to tax incentives and tax reduction and exemption policy support for cooperative organizations. The No. 1 Central Document's tax and fee support policy for cooperative organizations has three main characteristics: First, it attaches importance to tax and fee support for cooperative organizations that develop the acceleration and circulation of agricultural products. Second, pay attention to the tax registration of cooperative organizations as separate taxpayers and standardize the tax registration system. This is conducive to the implementation of tax support policies. Third, focus on providing key financial support to cooperative organizations that undertake national agriculture-related projects. 


\begin{tabular}{|c|c|c|c|c|}
\hline Years & Legal policy & Funding policy & Personnel policy & Tax policy \\
\hline 2004 & $\begin{array}{l}\text { 1.Actively promote the } \\
\text { legislative work on farmer } \\
\text { cooperative organizations }\end{array}$ & $\begin{array}{l}\text { 1.The central and local } \\
\text { governments must arrange } \\
\text { special funds } \\
\text { 2.Relevant financial } \\
\text { institutions support farmer } \\
\text { cooperative organizations }\end{array}$ & & \\
\hline 2005 & & & & $\begin{array}{l}\text { 1.Appropriate reduction and } \\
\text { exemption of tariffs and fees for } \\
\text { cooperative organizations and } \\
\text { their processing and circulation } \\
\text { entities }\end{array}$ \\
\hline 2006 & $\begin{array}{l}\text { 1.Actively guide and } \\
\text { support farmers to develop } \\
\text { various cooperative } \\
\text { economic organizations } \\
\text { and speed up the } \\
\text { legislative process }\end{array}$ & & & \\
\hline 2007 & $\begin{array}{l}\text { 1.Earnestly implement the } \\
\text { Farmer Cooperative } \\
\text { Organization Law }\end{array}$ & & & $\begin{array}{l}\text { 1.Taxation policies that are } \\
\text { conducive to the development } \\
\text { of farmers cooperative } \\
\text { organizations must be adopted }\end{array}$ \\
\hline 2008 & $\begin{array}{l}\text { 1.Fully implement the } \\
\text { Farmer Cooperative } \\
\text { Organization Law, and } \\
\text { promptly promulgate } \\
\text { supporting laws and } \\
\text { policies }\end{array}$ & $\begin{array}{l}\text { 1.Finances at all levels } \\
\text { must continue to increase } \\
\text { support for farmer } \\
\text { cooperative organizations }\end{array}$ & $\begin{array}{l}\text { 1. Organize and implement the } \\
\text { new rural practical talent } \\
\text { training project }\end{array}$ & $\begin{array}{l}\text { 1. Formulate tax incentives as } \\
\text { soon as possible }\end{array}$ \\
\hline 2009 & & & $\begin{array}{l}\text { 1.Strengthen the training of } \\
\text { personnel of cooperative } \\
\text { organizations, and provide } \\
\text { financial support from all } \\
\text { levels of finance }\end{array}$ & $\begin{array}{l}\text { 1.Incorporate cooperative } \\
\text { organizations into the tax } \\
\text { registration system and exempt } \\
\text { tax registration costs }\end{array}$ \\
\hline 2010 & & $\begin{array}{l}\text { 1.The new agricultural } \\
\text { subsidies are appropriately } \\
\text { tilted to large grain } \\
\text { growers and farmer } \\
\text { cooperative organizations } \\
\text { 2.Provide subsidies to } \\
\text { cooperative organizations } \\
\text { with strong service } \\
\text { capabilities and good } \\
\text { democratic management }\end{array}$ & & $\begin{array}{l}\text { 1.Loans supported by } \\
\text { governments at all levels are } \\
\text { favored by large grain growers } \\
\text { and farmer cooperative } \\
\text { organizations }\end{array}$ \\
\hline \multicolumn{5}{|l|}{2011} \\
\hline 2012 & & $\begin{array}{l}\text { 1.The new subsidies are } \\
\text { tilted to the main } \\
\text { production areas, large } \\
\text { planters and farmer } \\
\text { cooperative organizations } \\
\text { 2.Increase credit supply to } \\
\text { large farmers, farmer } \\
\text { cooperative organizations } \\
\text { and county-level small and } \\
\text { micro enterprises }\end{array}$ & $\begin{array}{l}\text { 1.Accelerate the training of } \\
\text { village cadres, large planters, } \\
\text { and farmer cooperative } \\
\text { organizations }\end{array}$ & \\
\hline 2013 & $\begin{array}{l}\text { 1.Quickly study and revise } \\
\text { the Farmer Cooperative } \\
\text { Organization Law }\end{array}$ & $\begin{array}{l}\text { 1.Continue to increase the } \\
\text { scale of agricultural } \\
\text { subsidies }\end{array}$ & $\begin{array}{l}\text { 1.Establish a talent pool for } \\
\text { cooperative organizations and } \\
\text { guide college graduates to }\end{array}$ & $\begin{array}{l}\text { 1.Improve preferential tax } \\
\text { policies for cooperative } \\
\text { organizations }\end{array}$ \\
\hline
\end{tabular}




\begin{tabular}{|c|c|c|c|}
\hline & $\begin{array}{l}\text { 2.Increasing development } \\
\text { funds for farmer } \\
\text { cooperative organizations }\end{array}$ & $\begin{array}{l}\text { work in cooperative } \\
\text { organizations }\end{array}$ & $\begin{array}{l}\text { 2.Exemption of business tax on } \\
\text { eligible agricultural business } \\
\text { service businesses }\end{array}$ \\
\hline 2014 & $\begin{array}{l}\text { 1.New subsidies are } \\
\text { provided to important } \\
\text { agricultural products such } \\
\text { as grains and new } \\
\text { agricultural operators } \\
\text { Tilting of body and main } \\
\text { producing area } \\
\text { 2.Allow financial project } \\
\text { funds to be directly } \\
\text { invested in eligible } \\
\text { cooperative organizations } \\
\text { 3.Encourage local } \\
\text { governments and private } \\
\text { individuals to fund the } \\
\text { establishment of financing } \\
\text { guarantee companies to } \\
\text { provide loan guarantee } \\
\text { services for new } \\
\text { agricultural business } \\
\text { entities }\end{array}$ & $\begin{array}{l}\text { 1.Intensify the education and } \\
\text { training of new-type } \\
\text { professional farmers, new- } \\
\text { type agricultural business } \\
\text { entities, and sports leaders }\end{array}$ & $\begin{array}{l}\text { 1.Implement and improve } \\
\text { relevant tax preferential policies }\end{array}$ \\
\hline 2015 & $\begin{array}{l}\text { 1. Gradually improve laws } \\
\text { and regulations covering } \\
\text { various production and } \\
\text { operation entities in rural } \\
\text { areas, and revise the } \\
\text { Farmer Cooperative } \\
\text { Organization Law in due } \\
\text { course }\end{array}$ & & \\
\hline \multicolumn{4}{|l|}{2016} \\
\hline 2017 & $\begin{array}{l}\text { 1.Encourage financial } \\
\text { institutions to actively use } \\
\text { Internet technology }\end{array}$ & $\begin{array}{l}\text { 1.Provide small deposits and } \\
\text { loans for rural business } \\
\text { entities }\end{array}$ & \\
\hline 2018 & & $\begin{array}{l}\text { 1.Innovate training } \\
\text { mechanism, support farmer } \\
\text { cooperative organizations, } \\
\text { professional technical } \\
\text { associations, leading } \\
\text { enterprises and other entities } \\
\text { to undertake training }\end{array}$ & \\
\hline 2019 & & $\begin{array}{l}\text { 1.Support the promotion of } \\
\text { agricultural technology by } \\
\text { supply and marketing, postal } \\
\text { services, agricultural service } \\
\text { companies, and farmer } \\
\text { cooperative organizations }\end{array}$ & \\
\hline 2020 & & & $\begin{array}{l}\text { 1.Eligible new agricultural } \\
\text { business entities can enjoy the } \\
\text { current tax reduction and } \\
\text { exemption policies for loans } \\
\text { related to small and micro } \\
\text { enterprises in accordance with } \\
\text { regulations }\end{array}$ \\
\hline
\end{tabular}

Figure 2. No. 1 central Document relates to a summary of the policy support of farmer cooperative organizations 


\section{Analysis}

According to the nature of the policy, policy tools are divided into three categories: mandatory policy tools, contract policy tools and interactive policy tools. Mandatory policy tools refer to policy tools formulated by the government based on authority. They are compulsory and exercised by the government from top to bottom. According to the formulation methods, they can be divided into laws and regulations, system construction, etc.; contract-type policy tools refer to government departments and Cooperation forms of other organizations are more flexible than compulsory policies, specifically including tax and fee concessions, capital investment, demonstration construction, etc.; interactive policy tools refer to relatively low levels of government intervention, adding market influence factors, and specific content There are talent training and so on. The policy documents of farmer cooperative organizations in 22 No. 1Central documents were sorted out. The policy texts of farmer cooperatives appeared 52 times, and the specific clauses of the policy texts were coded.

The policy tools of farmer cooperative organizations in our country are unevenly distributed. Contract-type policy tools are used most, accounting for $65.38 \%$, followed by mandatory policy tools, accounting for $19.23 \%$, and interactive policy tools are the lowest, being $15.38 \%$. Further analysis is as follows:

1. In terms of the use of contractual policy tools: attach importance to capital investment and demonstration construction, and contractual policy tools are used more, because farmer cooperative organizations are economic organizations formed spontaneously by farmers, and a large amount of capital investment is needed to support cooperative organizations in the early stage of development. Therefore, the government needs to continuously increase various subsidies to rural cooperative organizations.

2. Coercive policy tools and interactive policy tools are used less frequently, and the construction of related systems of farmer cooperative organizations is lagging behind, which has led to some cooperative organizations becoming private companies. The existence of cooperative organizations is to defraud state subsidies. The lack of talents is also the biggest shortcoming in the development of farmer cooperative organizations.

\section{Advice}

Through the comprehensive analysis of the central government's No.1 Central document farmer cooperative organization policy and the application of policy tools, it is found that my country's farmer cooperative organization construction has made significant achievements. The improvement of rural problems has led to the continuous improvement of the farmer cooperative organization system. Great changes have taken place in policy objectives, formulation methods, and implementation performance. The policies of farmer cooperative organizations basically cover all policy tools, but there are still some shortcomings in the development and improvement.

\subsection{Improve the Construction of Farmer Cooperative Organization System}

Because the farmer cooperative organization system is not sound, the behavior of some farmer cooperative organizations is not standardized, and some are used and controlled by a few people, and the rights of farmers to democratically manage cooperative organizations cannot be guaranteed. It is difficult to protect the legal rights of farmers. The government should use compulsory policy tools to improve the relevant systems of farmer cooperative organizations, and improve the accounting system and supervision system. Let farmer cooperative organizations operate under the common supervision of farmers.

\subsection{Cultivate Talents for Farmer Cooperative Organizations}

Cultivating talents for farmer cooperative organizations is a top priority, and the process of cultivating talents for cooperative organizations must be improved. It is mainly responsible for training the heads of cooperative organizations and member representatives, which is the institutionalization of the training of talents of cooperative organizations. It is necessary to focus on the introduction of college students, introduce a series of talent introduction policies, and cultivate high-quality talents for farmer' cooperative organizations. (Zhang Liangang \& Zhi Ling, 2016)

\section{References}

Wang, S. G. (2008). All-factor cooperation, government support and sustainable development of farmer cooperatives. Rural Economy, (11), 3-6.

Zhang, L. G., \& Zhi, L. (2016). Top-layer Design for the Development of Farmers' Cooperatives: Policy Evolution and Prospects. China Rural Survey, (05), 10-21+94. 


\section{Copyrights}

Copyright for this article is retained by the author(s), with first publication rights granted to the journal.

This is an open-access article distributed under the terms and conditions of the Creative Commons Attribution license (http://creativecommons.org/licenses/by/4.0/). 